- Gi rask respons på artikler gjennom artikkelens kommentarfelt på tidsskriftet.no. Respons som er postet innen én måned etter at artikkelen er publisert, vurderes for publisering som Brev til redaktøren i papirutgaven.

Redaksjonen forbeholder seg retten til å foreta redaksjonelle endringer.

Forfattere av vitenskapelige artikler har tilsvarsrett, jf. Vancouver-gruppens regler.

\section{Nokre ord om argumentasjonen til Malt}

Ved lesing av Ulrik Fredrik Malt sine merknader til artikkelen om 22. juli-saka som Alv A. Dahl hadde i nr. 12-13/2013 (1), er det vanskeleg å ikkje feste seg ved kor stor vekt Malt legg på ulike former for formell autoritet og kor lite plass han gjev til opne data som lesaren sjølv kan verifisere.

- Malt var til stades i lukka rett. Det var ikkje Dahl. Inga norsk rettssak har vore so breitt kringkasta og referert som Anders Behring Breivik-rettssaka. Likevel meiner Malt at vi som lesarar bør tilleggje dette stor vekt.

- Sidan det er ICD-10 som gjeld i Noreg, er DSM-IV automatisk irrelevant, meiner Malt. Kva då med at Oslo tingrett, i og med oppnemninga av Aspaas og Tørrissen, og utifrå ein uttalt motivasjon om å få saka best mogeleg opplyst, braut med det forventa og sedvanlege? Den spalteplassen Malt trass alt nyttar på fagleg forsvar for ICD-10, gjev ymt om at han kanskje ser at formalisme ikkje er noko overtydande argument.

- Med tilstrekkjeleg psykiatrisk opplysing av saka hadde dei psykiatriske ekspertane landa på same synspunkt som Malt. Ved slik å rette merksemda mot kor presis psykiatrien visstnok er, feiar Malt diagnoseusemja i rettssalen under teppet. Det vert noko å trekkje på skuldrene av. Eit uheldig unnatak. Harmoniseringsmodellen frå Malt står òg i kontrast til aktor Inga Bejer Engh, som i Aftenposten bad Per Egil Hegge om å «akseptere at det var ulike faglige oppfatninger av Behring Breiviks tilregnelighet» (2).

Alv Dahl framstår fyrst og fremst som tekstlesar. Han har lese dokumenta, domen og rapportane, og påviser ulikskapar, hol og manglar i dei. Og sidan publikum lett kan etterprøve Dahl (ved sjølve å lese dei same tekstene), ter argumentasjonen seg som open.

Malt kunne ha ettergått og eventuelt korrigert Dahl si lesing. I staden nyttar han spalteplassen til å insinuere om Dahl sin agenda og faglege isolasjon. Dermed framstår kommentaren frå Malt som ei avsporing.

\section{Leif Halvard Silli}

lhs@russisk.no

Leif Halvard Silli (f. 1968) er sjølvstendig næringsdrivande og skribent. Ingen oppgitte interessekonflikter.

\section{Litteratur \\ 1. Dahl AA. Erklæringer og dom i 22. juli-saken - hva kan vi lære? Tidsskr Nor Legeforen 2013; 133: 1289-90. \\ 2. Engh IB. Idiotstempling i den offentlige debatt. Aftenposten 23.4.2013. www.aftenposten.no/meninger/debatt/Idiotstempling-i-den-offentlige-debatt- 7182268.html (11.7.2013)}

Dette er en redigert versjon av et innlegg publisert som rask respons på nett 11.7.2013. http://tidsskriftet.no/article/3026750/

\section{Smertens tegn}

I Tidsskriftet nr. 12-13/2013 hadde Alv A. Dahl en interessant redegjørelse om 22. juli-vurderingene av psykose (1).

Psykoanalytiker André Green hevder at psykosen utvikles på grunn av tilbaketrekning av investeringer, eller mer radikalt, som desinvestering. Personen dyrker tegnet og er gjennomarbeidet av rollene (2), som han går opp i - for eksempel som «ridder» eller «offiser». Tegnene er meningsbærende for personen, men de er ikke selve meningen. De grandiose symbolene, uavhengigheten og rekvisittene dekker til personens sårbarhet.

Depersonaliseringen påvirker personens forestillinger om andre og affekten i forhold til dem. I tilfellet Breivik kan de «fremmede» muslimene reflektere personens opplevelse av å føle seg fremmed i verden. Det fortrengte stoffet truer med å overmanne ham. Lacan skriver: » Ved å utrydde objektet prøver subjektet å kvitte seg med avhengigheten (til objektet) og bli «allmektig» (3). Subjektet sanser en totalitet ved seg selv som gir vedkommende følelsen av seier (overlevelse). Men denne grandiositeten er tett knyttet til avhengighet/depresjon. Det eneste som kan holde subjektet fra en utagerende handling er å få depresjonen - negativiteten - i tale (3).

Terje Tørrissen og Agnar Aspaas uttalte at Breivik ikke viste tegn til «uklar identitetsopplevelse» (4). Dikemark-teamet observerte verken «kognitiv funksjonssvikt eller tankeforstyrrelser» (4). De eksterne politiske ideene som ble eksponert av Breivik, viser imidlertid etter mitt skjønn klar forstyrrelse. De totale konstruksjonene (den «muslimske trussel») og de tankeforstyrrende formene (Knight-Templar-ridder, drapsmandat) er sannsynligvis forankret i en psykose. Breivik ble så vidt jeg kan skjønne styrt av hallusinasjoner som rommer forfølgelsesangst, følelse av å ha kontroll over andres liv og tanker og mandat til å drepe.

Hallusinasjonen rommer en illusjon som kan gjenkjennes i ridderuniformen. Ifølge André Green utgjør slike forkledninger forsøk på å forme et ideal. Bakgrunnen er en narsissisme som prøver å lure det sårbare jeget med megalomani og holocaust (2). I Breiviks tilfelle ble forestillingen om muslimene til en psykotisk konstruksjon - et Eurabia. Angstferden på Utøya ble gjort ved en metonymisk kobling til «muslimene» - via assosiasjonen «multikulturell».

Leser vi Breivik slik, kan vi se en alvorlig dysfunksjon i persepsjonsnivået. Personen nekter å erkjenne realiteten i sin forestilling om drapsmandat som psykotisk. Premisset for diagnosen til Synne Sørheim og Torgeir Husby var at det eksisterer et absolutt drapsforbud i lovteksten. Drapstankene var - ifølge de sakkyndige psykotisk konstante i vrangforestillingen. Personen kan intellektuelt vite om sensuren, men kjenner ikke til sin værens død, sin sårbarhet.

Psykosen viste seg i Breiviks brev til mediene. Etter min mening innebærer den ubehandlede tilstanden en selvmordsrisiko som ikke hører hjemme i et fengsel.

\section{Heidi Stakset}

heidi-stakset@hotmail.com

Heidi Stakset (f. 1966) er lektor ved Strinda videregående skole. Ingen oppgitte interessekonflikter.

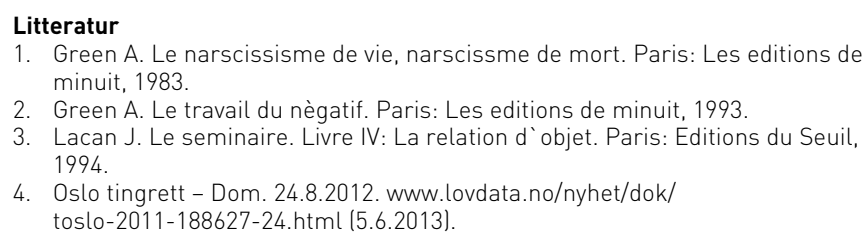

Dette er en redigert versjon av et innlegg publisert som rask respons på nett 5.6. 2013. http://tidsskriftet.no/article/3026750/ 